
\title{
R Research Soure \\ Environmental Factors Determinate Roadkill Levels of the Endemic Iberian Species, Iberian Hare (Lepus Granatensis)
}

Jesús Duarte

Ofitecma Marbella

David Romero ( $\square$ davidrp_bio@hotmail.com )

University of Malaga

\section{Pablo Rubio}

Delegación de Medio Ambiente, Oficina Técnica, Mancomunidad de Municipios de 9 la Costa del Sol Occidental

Miguel Ángel Farfán

University of Malaga

Julia Fa

University of Manchester

\section{Research Article}

Keywords: Lepus granatensis, Environmental factors, roadkill levels, Iberian species, Iberian hare, Iberian Peninsula

Posted Date: June 2nd, 2021

DOl: https://doi.org/10.21203/rs.3.rs-569721/v1

License: (9) This work is licensed under a Creative Commons Attribution 4.0 International License. Read Full License 
1 Environmental factors determinate roadkill levels of the endemic Iberian species, Iberian hare (Lepus granatensis)

3 Jesús Duarte ${ }^{1 \S}$, David Romero ${ }^{2 * \S}$, Pablo J. Rubio ${ }^{3}$, Miguel A. Farfán ${ }^{2 \#}$, Julia E. Fa ${ }^{4 \#}$ 4

$5 \quad{ }^{1}$ Ofitecma Marbella, Av. Ramón y Cajal 17, 29601 Marbella, Spain.

$6 \quad{ }^{2}$ Biogeography, Diversity and Conservation research group, Department of Animal

7 Biology, Faculty of Sciences, University of Málaga, E-29071 Málaga, Spain.

$8{ }^{3}$ Delegación de Medio Ambiente, Oficina Técnica, Mancomunidad de Municipios de

9 la Costa del Sol Occidental, Calle de Bonanza s/n, 29604 Marbella Spain.

$10{ }^{4}$ Manchester Metropolitan University, Division of Biology and Conservation

11 Ecology, Manchester, United Kingdom.

12 *Corresponding author; Email: davidrp@uma.es.

13 §ex aequo contribution of both authors

$14 \quad$ "co-senior author

16 Abstract

17 Lepus granatensis is an Iberian Peninsula endemic species and one of the most 18 important small game species. We surveyed Iberian hare-vehicle accidents in roads 19 network in southern Spain, analysing the Mediterranean landscape, the main habitats 20 of this species. We recorded roadkill of roads during 6-month, compared hare roadkill 21 densities to hare hunting yields. We analyzed the spatial patterns and factors that 22 could be influencing the hare road kill. We detected blackspots of hare road kill in 23 areas with high landscape heterogeneity and included embankments, intersections 24 roads and high traffic intensity. The hare roadkill ranged between $6 \%$ and $41 \%$ of the 25 annual harvest of hares killed on neighbouring hunting estates. We therefore consider 
it highly relevant to take into account the hare road kill, especially in hare hunting areas, suggesting to gamekeepers and managers addressing the issue of road kill of hares. It would be necessary that hunting quotas be adjusted in territories where the additive effect of these non-natural hare mortalities converge. Results point to future directions for applied research in road ecology, which would include demographic compensation and roadkill mitigation. Our methodology could be of wide use to identify lagomorphs' road kill blackspots by analysing environmental spatial patterns.

\section{Introduction}

Roads have a widespread impact on wildlife populations through landscape fragmentation, loss of connectivity, and the emergence of corridors favouring anthropogenic species or predators, as well as by direct mortality from roadkill (1), identified as one of the main threats to the conservation of mammals in the world (2).

Roads can cause the decline of the carrying capacity of a species through habitat destruction and modification in boundaries of up to 100 meters on both sides of the roads (3). Human activity and traffic intensity near the road can also disturb the adjoining habitats (4). Environmental disruption by the roads are interrupting biological activities that require the movement of animals, such as reproduction, feeding, or dispersal, resulting in genetic isolation $(5 ; 6)$ and affecting the demographic characteristics, their spatial distribution and abundance of species $(7 ; 8)$.

A large number of species are affected by road collisions, from large vertebrates, mesocarnivores $(9 ; 10 ; 11)$ to smaller species $(12 ; 13 ; 14 ; 15)$. Road mortality affecting the European hare (Lepus europaeus) $(16 ; 8 ; 17)$ as well as other non-Mediterranean hare species $(18 ; 19 ; 20)$ has been published. However, detailed analyses of road mortality of these are scarce. 
The Iberian hare (Lepus granatensis) is endemic to the Iberian Peninsula (21).

52 Hares are largely nocturnal, medium-sized lagomorphs that inhabit pastureland,

53 farmland, plains, and forests, as well as scrubland areas in mountains in the northern

54 range of their distribution (22). The ecological role of the Iberian hare is essential for

55 the configuration and maintenance of Mediterranean landscape ecosystems (21). On

56 the other hand, we expected that currently spatial configuration of the Mediterranean

57 ecosystem could be determinate the areas of hare roadkill aggregation (13). Although

58 hares are important game animals (23), little is known about their population biology

59 and demography $(24 ; 25 ; 26 ; 27)$. Specifically, although recently new policies are

60 being proposed for the wildlife manager, only a few studies have quantified non-

61 hunting mortality rates, and very few have proposed to analyse the additive effect of

62 hunting and roadkill on game species (28). Between $13 \%$ and $38 \%$ of the hare

63 populations studied are known to be affected by predation, disease, and environmental

64 events (i.e. floods) $(29 ; 30)$. Although it is known that roadkill has adverse effects on

65 wildlife $(6 ; 13)$, few studies have specifically addressed Iberian hare roadkill.

66 Sánchez-García et al. (30) suggested that in the north of its distribution range in

67 Spain, only a small part of its mortality (9\%) is due to roadkill. Hare roadkill is likely

68 to be more frequent in southern Spain, where there are large areas dedicated to

69 growing cereals, sunflowers, grapes, and olives (31).

70 Seiler et al. (17) emphasized the relevance of roadkill for some game species,

71 such as hares, suggesting that the ratio of collisions to annual harvests should be taken

72 into account in the management of populations. In Andalusia (a region in the south of

73 Spain), the average annual hare harvest can range from 0.8 hares $/ \mathrm{km}^{2}$ to 20.9

74 hares $/ \mathrm{km}^{2}$ (32). In fact, almost 250000 hares are hunted per year (33), which clearly

75 shows the economic importance of this species. It is relevant to understand the 
ecological factors that increase mortality in hare populations, given the taxonomic importance of this endemic species and the significant role it plays in the ecology and rural economy of this region. Demographic compensation is a frequent response in short-lived species (34) such as the Iberian hare. Therefore, roadkill, as a type of additive mortality, must be taken into account in management or hunting plans for this species.

Identifying relationships between road-kill hare patterns and landscape is essential to propose mitigation measures for conservation purposes. This study assessed Iberian hare roadkill within a large distribution area in southern Spain. We hypothesised that, apart from hunting activities, road mortality may be a significant cause of death of this species and thus affect its population ecology. We quantified roadkill rates and compared them to the harvesting rates recorded on neighbouring hunting estates. We also identified blackspots with high roadkill rates and the factors likely to be associated with these. Finally, we propose management measures for the conservation of these populations, applicable to other territories and scales.

\section{Material and methods}

Study Area

The study was conducted in Antequera County ( $\left.37^{\circ} 10^{\prime} \mathrm{N}, 4^{\circ} 37^{\prime} \mathrm{W}\right)$, located in northeast Malaga province (Andalusia, southern Spain) during 2003. The area's climate is continental Mediterranean, with mean temperatures of $26^{\circ} \mathrm{C}$ in August and $9{ }^{\circ} \mathrm{C}$ in January. Annual rainfall is $550 \mathrm{~mm}$, concentrated between October and May.

8 Summers are dry and hot, and winters cold. Days with snow are rare, although frost may occur in winter since nighttime temperatures may fall to below $-3^{\circ} \mathrm{C}(35)$. 
The area is a relatively flat (400 - 550 m.a.s.1.) fertile plain, mainly covered by

101 farmland (more than 80\%). Road density in the area was $26.9 \mathrm{~km}$ per $100 \mathrm{~km} 2$ (36).

102 Olive groves, vineyards, sunflower fields and cereal lands or other dry herbaceous

103 crops are typical crops. Natural vegetation is concentrated along the adjoining hills or

104 small habitat islands within or between crops. These are dominated by scattered holm

105 oak (Quercus rotundifolia), wild olives (Olea europaea var. sylvestris) and dense

106 scrubland consisting of rockroses (Cistus spp.), lentisc (Pistacia lentiscus) and various

107 Labiatae (37). Other natural vegetation types are present along hedges, crop

108 boundaries and road borders where there is a predominance of an annual herbaceous

109 and nitrophilous plant community (38). Hare abundance in the study area was

110 relatively high. The habitat in the region is considered very favourable for hares and is

111 amongst the most auspicious for the species in Andalusia (39).

112

113 Data collection

114 We selected a total of seven main roads within the study area to perform our

115 roadkill counts (Table 1). The sampled area comprised a square of $30 \mathrm{~km}$ sides which

116 included a total length of $55.7 \mathrm{~km}$ of roads that cross seven municipalities (Fig. 1). All

117 roads were comparable, containing two lanes, one in each direction, an asphalt surface

118 6-7 meters wide and with sides of 1-2 meters wide. Maximum speed in all these roads

119 was $90-100 \mathrm{~km} / \mathrm{h}$, although some sections had speed limits. The mean traffic intensity

120 for 2006 was nearly 1,000 vehicles/day, ranging from 500 to 2,000 (36). All roads

121 were unfenced, thus allowing wildlife movement and access to the surrounding

122 vegetation. There were verges with vegetation between the roads and the surrounding

123 cropland. We excluded highways because these are all fenced, within which we did

124 not detect roadkills during a prior sampling. 


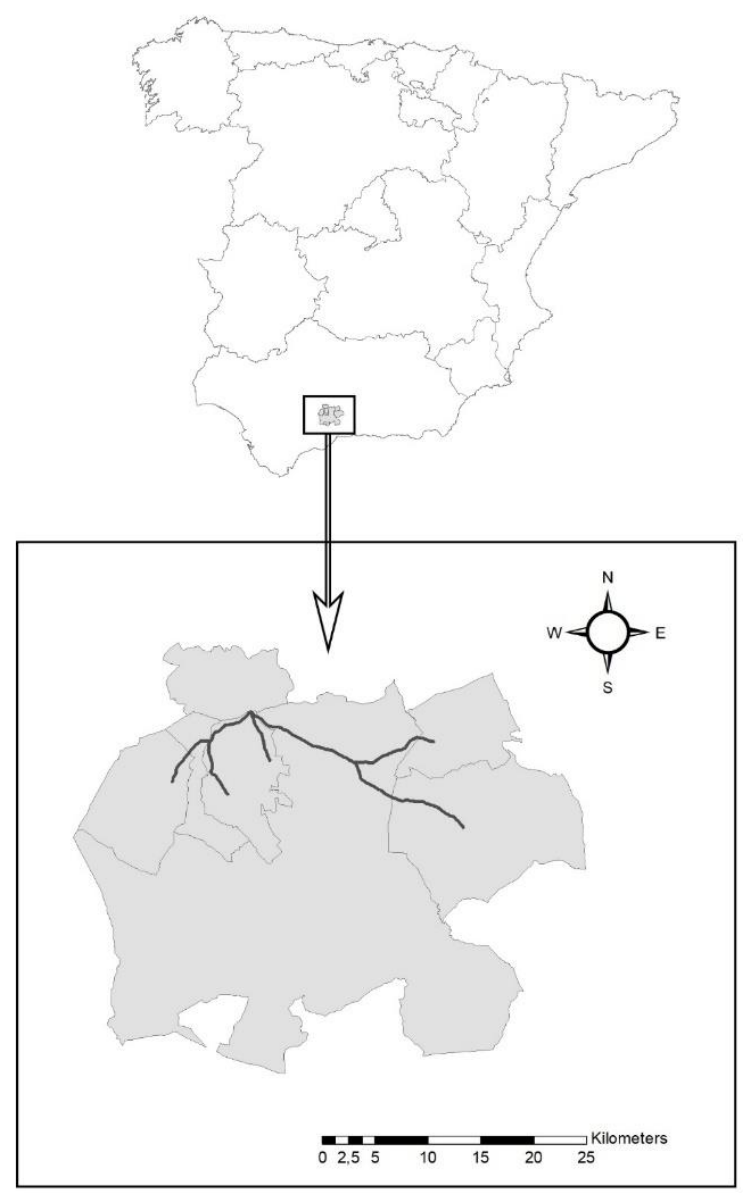

125

Fig. 1 Location of the study area in the northeast of Malaga province to the

127 southern of Spain. Stretches of highways analysis for hare roadkills $(55.7 \mathrm{~km})$.

128

129

130 Table 1. Features of the roads sampled in the study area. Road length is given in

131 kilometres. Traffic volume represents the average number of vehicles/day estimated 132 on the road (Junta de Andalucía, 2006).

\begin{tabular}{llcc}
\hline Road code & Name & Length & $\begin{array}{c}\text { Traffic } \\
\text { Volume }\end{array}$ \\
\hline MA-5101 & Archidona - Villanueva de Algaidas & 12.7 & 500 \\
MA-6414 & Villanueva de Algaidas - Córdoba & 11.8 & $1000-2000$ \\
MA-6415 & Córdoba - Alameda & 8.9 & $1000-2000$
\end{tabular}




\begin{tabular}{llcc} 
MA-6409 & Alameda - Los Carvajales & 5.1 & $500-1000$ \\
MA-6410 & Los Carvajales - Mollina & 5.8 & $500-1000$ \\
MA-6408 & Los Carvajales - Fuente de Piedra & 5.7 & $500-1000$ \\
S/C & Alameda - Cortijo Peinado & 5.7 & 500 \\
& Total & 55.7 & \\
\hline
\end{tabular}

133

Roads were surveyed weekly for a total period of six months, between March 1, 2003 and July 31, 2003. This is the period of maximum reproductive activity for hares in the region (26). Three surveyors were present in each survey (always the same during the study period to avoid inter-observer biases). Surveys were driven in a car vehicle at $10 \mathrm{~km} / \mathrm{h}$. To survey by foot was not allowed by the police in these roads. Before undertaking the first sampling, we cleaned and removed all carcasses on the sampled road sections. Surveys were carried out at dawn. We recorded the UTM coordinates of each collision point using a GPS eTrex Vista Cx (Garmin, USA).

When a carcass was detected, we removed it to avoid double counting during subsequent sampling. All other wild species killed by vehicle collisions were also recorded. Kill rates were standardized as the number recorded per $100 \mathrm{~km}$ (19). We investigated whether hare roadkills were aggregated in certain road sections i.e., blackspots. We considered two approaches for this estimating the possible aggregation in 100-m and 500-m road sections. These distances have been proposed to be as far as the road habitat disturbance effect reaches (4). In addition, we also computed the density of roadkills in two $100 \mathrm{~m}$ and $500 \mathrm{~m}$ buffer radios, as the number of hares killed per $\mathrm{km}^{2}$.

To compare hunting bags with hares killed on roads, we used the annual hunting reports (AHRs) for the period 1993 to 2001 from 181 game estates. These were all the fame estates that in the seven municipalities which were traversed by the sampled roads. We analysed 1,282 AHRs from these game estates and estimated the hunting 
155 yield (HY) as $\sum$ mean annual number of hares hunted per game estate / $\sum$ areas of the

156 game estates in $\mathrm{km} 2(40 ; 41 ; 42)$. Hunting data were taken from Farfán (32).

157

158

159

160

161

162

163

164

165

166

167

168

169

170

171

172

173

174

175

176

177

178

179

\section{Roadkill modelling}

The number of collisions for any target species depends on a number of factors related to road features and traffic volume $(43 ; 44)$, animal behaviour and phenology $(45 ; 46 ; 7)$. The surrounding habitat structure and landscape can also play an important part $(1 ; 14 ; 47)$. To consider the incidence of these possible factors in our sample, we overlaid hare collision points on habitat maps derived from digital orthophotographs (scale $0.5 \mathrm{~m} /$ pixel) using ArcGis 9.3 software (Esri, USA). All roads containing the collision points were also digitized onto the habitat maps. We measured variables related to road features, surrounding habitat and landscape (Table 2) at each collision point. We used two sampling levels: a buffer of 100-m radius around each collision point for the habitat level (see 48; 49) and another buffer of 500-m for the landscape level (50). At the habitat level, we estimated crops and classes of vegetation present and the surface area of each vegetation patch. We also estimated habitat diversity using the Shannon index (51). At the landscape level, we measured the ecotone length and also estimated land heterogeneity using the Baxter-Wolfe interspersion index $(52 ; 53)$ along a transect perpendicular to the road.

Table 2. Variables measured to model the factors that affect hare-vehicle collision locations. Road features were measured at each collision point. The habitat level variables were measured in a 100-m radius buffer around any hare accident point whereas the landscape level variables at a 500-m radius buffer. P/A, presence/absence. 


\begin{tabular}{ll}
\hline Code & Definition \\
Road features & \\
Traffic & Traffic volume estimated in the road (vehicles/day; classes: $1<500 ;$ \\
& $2,500-1000 ; 3,1000-2000)$ \\
Cross & Distance to nearest crossroad (m) \\
Embankment & Presence of embankment (road above surrounding land) (P/A) \\
Slope & Presence of lateral cutting (road below surrounding land) (P/A) \\
Ditch & Presence of marginal ditch (P/A) \\
\hline Habitat level & \\
Crops & Total surface covered by crops (ha) \\
Natural & Total surface covered by natural vegetation (ha) \\
Diversity & Patch diversity (Shannon index), crops and natural vegetation \\
\hline Landscape level \\
Ecotone & Total ecotone length (km) \\
Heterog & Landscape heterogeneity (Baxter-Wolfe interspersion index) \\
\hline
\end{tabular}

We also generated random points without hare-vehicle collisions on these roads

182 as controls in the statistical tests. We applied the same procedures as used with the

183 buffers and environmental variable measurements.

Data analysis

186 We tested if the spatial pattern of collisions in road sections fitted a pattern

187 expected at random through the Wald-Wolfowitz run test (54). If the random

188 hypothesis was rejected, we estimated a spatial index of dispersion as the

189 variance/mean ratio. If this ratio yielded values $>1$ hares roadkills were dispersed as

190 contagiously objects (55) in those road sections.

191 To detect potential multicollinearity between variables, we developed a

192 correlation matrix and obtained a Spearman's rank correlation coefficient (rho). Based

193 on this value, the coefficient of determination $\left(\mathrm{R}^{2}\right)$ and the value of the Variance 
194 Inflation Factor (VIF) were calculated to measure possible collinearity between

195 variables (VIF > 5, 56), removing one of the variables involved in the cases. Only

196 those that captured the effects of any set of highly correlated variables were allowed

197 to continue. The VIF statistic was calculated as:

198

$$
\mathrm{VIFi}=1 /(1-\mathrm{R} 2 \mathrm{i}) \text {. }
$$

We generated predictive models for hare roadkills using a GLMM with a binomial error distribution and a logit link function (57) to test if the probability of detecting a hare collision was related to any of the road and environmental factors. The different roads sampled were the random factor, collision points were the presences and the random point without collisions the absences. We selected the model with the lowest Akaike's Information Criterion (AIC) (58). The SPSS 24.0 software package (IBM, USA) was used for the statistical analysis. Means are given with their standard errors.

\section{Results}

A total of $1,336.8 \mathrm{~km}$ of roads were sampled during the study period. The field effort involved 171.9 observer-hours. Over a period of 6 months, we recorded a total of 162 dead animals; $68.5 \%$ Iberian hares, $17.9 \%$ wild rabbits, $4.9 \%$ other mammals, $5.6 \%$ birds, and $3.1 \%$ reptiles (Table 3 ). Of the 111 hares found dead near the roads, only 80 could be clearly attributed to a vehicle collision; these were taken into account for further analysis. We estimated a standard kill rate for the area of 6.0 hares/100 km.

Table 3. List and frequencies of the species found during sampling animal-vehicle accidents in the study area (March-July 2003). 


\begin{tabular}{lcc}
\hline Species & $\mathrm{n}$ & $\%$ \\
\hline Mammals & 111 & 68.52 \\
Iberian hare (Lepus granatensis) & 29 & 17.90 \\
Wild rabbit (Oryctolagus cuniculus) & 2 & 1.23 \\
Rodents (Rattus sp.) & 2 & 1.23 \\
Western hedgehog (Erinaceus europaeus) & 2 & 1.23 \\
Red fox (Vulpes vulpes) & 1 & 0.62 \\
Common genet (Genetta genetta) & 1 & 0.62 \\
Western polecat (Mustela putorius) & & \\
Birds & 6 & 3.70 \\
Little owl (Athene noctua) & 1 & 0.62 \\
Short-toed eagle (Circaetus gallicus) & 1 & 0.62 \\
Red-necked nightjar (Caprimulgus ruficollis) & 1 & 0.62 \\
Mallard (Anas platyrhynchos) & & \\
Reptiles & 162 & \\
Montpellier snake (Malpolon monspessulanus) & 3 & 1.85 \\
Other snakes & 2 & 1.23 \\
Total & & \\
\hline
\end{tabular}

Hare roadkills were not randomly distributed neither in 100-m road sections

221 (test Wald-Wolfowitz; $\mathrm{N}=552 ; \mathrm{Z}=-5,782 ; \mathrm{p}<0,001$ ) nor in 500-m sections (test

222 Wald-Wolfowitz; $N=113 ; \mathrm{Z}=-4,024 ; \mathrm{p}<0,001)$ suggesting the possible existence

223 of black spots. However, the variance/mean ratio was only $>1$ in the 500-road sections

$224(0.71 \pm 0.12$ hares killed per section; $\mathrm{s} 2=1,21)$ confirming the existence of black

225 spots at least in road sections from this size onwards. A total of $68.7 \%$ of the hare

226 accidents were concentrated in $18.8 \%(10.5 \mathrm{~km})$ of the road network sampled (Fig. 2). 


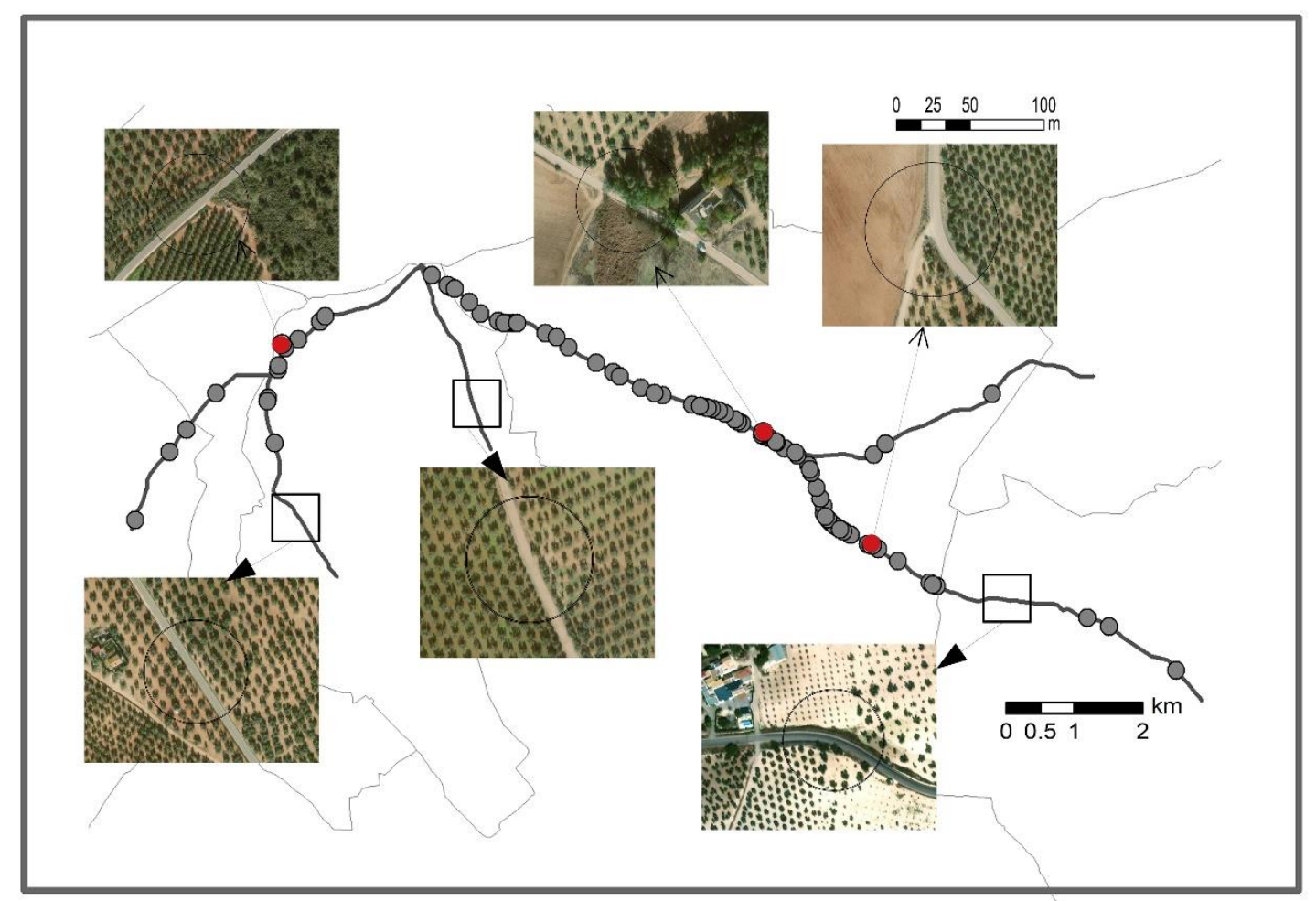

228 Fig. 2 Spatial study context. Grey and red circles indicate the points with hare roadkill

229 events; the red circles, those hare roadkill points that we have added a photograph

230 with the around $100 \mathrm{~m}$ buffer habitat (showing heterogeneous habitats). Rectangles

231 indicate some points without hare roadkill detected which we have added a

232 photograph with the $100 \mathrm{~m}$ buffer habitat (showing homogeneous habitats).

234 Density of hares killed on the roads was $4.6 \pm 0.5$ hares $/ \mathrm{km} 2$ in 100 -m buffers

235 and $0.9 \pm 1.4$ hares $/ \mathrm{km}^{2}$ in $500-\mathrm{m}$ buffers. The hunting yield in neighbouring game

236 estates was $15.1 \pm 14.8$ hares $/ \mathrm{km}^{2}$. Therefore, roadkills can account between $8 \%-$

$23740 \%$ of hares hunted in the area (Table 4).

239 Table 4. Hare accident density in the study area and ratio to hare hunting yields in 240 neighbouring hunting estates (period 1993-2001). Means \pm standard error and 95\% 241 confidence intervals estimation. NAHR = Number of annual hunting reports analysed;

242 NGE $=$ Number of game estates. 


\begin{tabular}{|lcc|}
\hline & Hares/km $\mathbf{k m}^{\mathbf{( 9 5} \% \text { C.I. })}$ & $\begin{array}{c}\text { Roadkills / Hunting yields } \\
(\boldsymbol{\%})\end{array}$ \\
\hline $\begin{array}{l}\text { 100-m Buffer } \\
(\mathrm{N}=552)\end{array}$ & $4.6 \pm 0.5(3.6-5.6)$ & $39.7(37.1-41.5)$ \\
\hline $500-\mathrm{m}$ Buffer & $0.9 \pm 1.4(0.6-1.2)$ & $7.8(6.2-8.9)$ \\
$(\mathrm{N}=113)$ & & \\
Hunting yields & $11.6 \pm 0.96(9.7 \pm$ & \\
$\left(\mathrm{N}_{\mathrm{AHR}}=485 ; \mathrm{N}_{\mathrm{GE}}=\right.$ & $13.5)$ & \\
$71)$ & & \\
\hline
\end{tabular}

The test for multicollinearity did not show any VIF $>5$. The best model $(\mathrm{AICc}=$ $811.473)$ classified correctly $92.5 \%$ of the accidents $(n=80)$ and $88.9 \%$ of the

246 random points without collisions $(n=81)$. The accident points were significantly

247 associated mainly with the landscape heterogeneity and secondly with the road

248 (embankments, crossroads and traffic volume). A highly heterogenous landscape, the 249 presence of embankments, a nearby crossroad, and high traffic volume were the main 250 factors influencing the hare accidents (Table 5).

252 Table 5. Results of the GLMM model fitted to differentiate between hare-vehicle 253 collision points and random points without collisions. Model coefficients are shown 254 with their standard error and Wald significance test. The random factor was the road 255 sampled. Significant $\mathrm{P}$ values were considered at $\mathrm{P}<0.05$.

\begin{tabular}{lcccc}
\hline Source of variation & $\mathbf{B} \pm \mathbf{S E}$ & d.f. & Wald & $\mathbf{P}$ \\
\hline Landscape heterogeneity & $1.547 \pm 0.347$ & 1 & 19.899 & $<0.001$ \\
Presence of embankment & $2.729 \pm 0.616$ & 1 & 19.661 & $<0.001$ \\
Distance to nearest crossroad & $-0.207 \pm 0.073$ & 1 & 8.094 & 0.005 \\
Traffic volume in the road & $2.789 \pm 0.740$ & 2 & 7.493 & 0.001 \\
\hline
\end{tabular}


Implications of the hare's roadkill on its conservation

Our results indicated that in the study area more than half of all reported vertebrate roadkills were Iberian hares. This frequency is higher than that observed numbers for ungulates or other medium and large-sized mammals $(59 ; 1)$ and for other hare species $(19 ; 20)$. The standard kill rate is also almost five times higher than for other studied hare species $(18 ; 17)$ and noticeably striking in contrast with the percentage of mortality reported by Sánchez-García et al. (30) for the species' road accidents in the north of Spain. We also found that almost two-thirds of the hare roadkill were concentrated in road blackspots. Such spatial aggregation has also been reported for other mammal species $(13 ; 60 ; 61)$. Given that mortality is concentrated in clearly defined road sections and are not at random points, mitigation measures (i.e. fencing, culvert design, verge management, crossing structures) could then be focused on these clusters (62).

However, the question arises of whether these results are representative of other areas in which the species is present. Our conclusions are limited due to the short study period and a lack of replicates. In this sense the results must be considered just as preliminary with regards to the species' road ecology. Further, smaller animals are readily missed during driven surveys, which could skew the frequencies of roadkill reported (63). Even so, we are confident that our data suggests that road mortality of hares is not insignificant and must be taken into account. Two-lane roads make up $89.4 \%$ of all Andalusian roads (36), hence the roads sampled in our study are representative of secondary roads throughout Andalusia. Fertile plains in Andalucía represent $31.1 \%$ of the regional landscape (64) as well as olive groves, vines and cereals cover $26.6 \%$ of the soils (65). Therefore, the landscape conditions, soil use, and road network in the study area are typical of almost a third of the region. 
An important third limitation of the study arises from research evidences

284 published some years after our sampling period. Santos et al. (66) shown that small mammal carcasses, like lagomorphs, do not persist on roads more than one to two days, being lower specially in summer due to same factor as scavengers, weather conditions or people removing them. This suggest that for a study like ours the optimal monitoring frequency should have been daily and not weekly. Further, this

289 divergence in the weekly vs daily sampling could involve an important false negative rate in the estimated hotspots, missing "true" hotspots (67). In the case of lagomorphs,

291 these authors suggest an underestimation of about $40 \%$ which implies that our

292 estimated roadkill mortality rate is much lower than real, and some hotspots were

293 missed. In any case, this divergence evidences the relevance of hare road mortality in

294 the area and enhances our results because an underestimation supposes a higher 295 source of additional mortality and bias to hunting planning.

296 An additional consideration about the representativeness of our results is related 297 to hare density. It has been argued that road casualty counts are not correlated to 298 population densities and that traffic flow is the most important explanatory variable 299 considering variance in road accidents for certain taxa $(68 ; 69)$. However, although 300 traffic has a role to play, in the case of wild rabbits a density dependent relation 301 between roadkills and the population living in wider landscapes has been shown (70;

302 71). This direct relationship may suggest something similar is affecting the Iberian 303 hare. In fact, this relationship is true for hare hunting yields (72) since higher hare 304 densities and more yields in fertile plains in which dry wood crops and irrigated 305 herbaceous crops are intensively managed (23) such as in our study area. 306 Finally, although our study period was short it agrees with the species' 307 maximum reproductive activity. D'Amico et al. (46) has highlighted the relevance of 
308 phenology as the most important factor affecting temporal roadkill patterns in small

309 mammals as well as Canal et al. (63) showed that these kinds of patterns were

310 repeated over years and ecoregions in a same region as Andalucía. Therefore, it is

311 likely that our results may be repetitive in similar conditions of environments, road

312 features and hare population status, showing the existence of an unknown hare

313 mortality rate and giving them relevance for the species management (73).

Hunting and roadkill hares; a risk of additive mortality

316 Roadkill data have been used to improve species management planning both in 317 endangered $(74 ; 75)$ and game species $(76 ; 77 ; 78)$. Different authors has emphasized

318 the general value of roadkill monitoring and its applications in some relevant

319 ecological fields (i.e. source of information for population trends, dominance patter in 320 species composition, mapping invasive species or contaminants and diseases; $73 ; 79$ ).

321 However, vehicle-accident data for smaller game species are often neglected for these 322 species' management planning (71).

323 In the case of hunting, the consideration of sources of additional mortality is 324 fundamental because of its effects on the species' population dynamics $(80 ; 34)$ and 325 could affect extraction rates (81). Some authors consider vehicle collision mortality as 326 an additive source of mortality $(82 ; 83)$ and even a population sink (84). Therefore, 327 hares killed in collisions may represent individuals that would not die if this cause of 328 mortality did not exist. Moreover, hunting mortality is considered partially 329 compensatory (i.e. to have died due to another reason if individuals not hunted) 330 whenever harvest rates are low (85). However, at higher harvest rates hunting 331 mortality may also be additive. In such situations, harvest management should also 332 take into account unnatural sources of mortality and these controlled. 
Iberian hare population trends have changed significantly since our study

334 period. It is assumed that Iberian hare populations have decreased almost $49 \%$ from

3352012 to present (86). In Andalusia these authors have also estimated a 16\% global

336 reduction in the species' hunting yields. In Málaga province alone, hunting yields

337 have dropped from 5.7 hares $/ \mathrm{km}^{2}$ (period 1993-2002; 32) to 1.7 hares $/ \mathrm{km}^{2}$ (period

338 2017-2018; 85). In such conditions, even a small road mortality rate should be

339 considered relevant and likely additive, especially when new diseases are also

340 threating the species $(87 ; 88)$.

341 It has been argued that the high reproductive potential of the Iberian hare

342 facilitates recruitment to populations and could make up high hunting pressures even

343 in low density scenarios (27). In such situations or where high densities of hares exist

344 or it is possible that the number of hare road-killed could be insignificant. However,

345 when populations are declining and diseases are also affecting these, road kills should

346 be considered since even a lower number of accidents would have a clear density

347 dependent relationship. The combination of natural mortality, diseases and roadkills

348 as well as ineffective hunting plans could drive populations into collapse. Regrettably,

349 demographic compensation via increased fecundity of remaining Iberian hare

350 populations is an understudied topic in road-dominated environments despite of

351 possibly play a central role in the population growth and hare-vehicle accidents.

353 Factors causing hare-vehicle collisions

354 As other authors detected for other lagomorph species (L. europaeus in Brazil)

355 (2), landscape heterogeneity is the main factor influencing Iberian hare fatalities.

356 Mixed patches of forested areas with pastureland or farmland create habitat mosaics

357 where an increase of resource availability for wildlife tends to increase the presence 
358 of species and then the likelihood of crossing nearby roads $(11 ; 1)$. The proximity of

359 forests to open areas is also a key factor in collisions (89). Road borders and verges

360 may act as feeding areas for some species (14) as well as they occur during regular

361 animal movement in their home range (90).

362 Forested areas in our study area are made up by olive groves, a woody crop that

363 allow water to become available to smaller species due to their widespread trickle

364 irrigation systems, as well as providing food resources (91). It is also worth

365 considering that weather conditions or seasonal variations affecting food availability

366 influence roadkill rates (92). This is a likely effect in the dry summers of the study

367 area that could push hares to cross roads looking for available water. Vineyards also

368 provide refuge, water and food. It should be noted that the Iberian hare follows a

369 heterogeneous habitat selection pattern and move frequently between habitat patches

370 (22). Therefore, hares may cross roads in points of high landscape heterogeneity in

371 search of food (i.e.: herbaceous crop shoots, weeds or early summer grapes); looking

372 for roadside vegetation or road verges (8); because of changes in food availability due

373 to harvesting (93), drove by farm works or machinery (94); or simply because it's the

374 rooting season and they are looking for mates in high diversity patches.

375 We identified the presence of embankments as the second factor favouring hare

376 accidents. Some authors have suggested that embankments may act as barriers that

377 prevent animals from crossing the road (95), and collisions occur when the road and

378 the adjacent landscape are at the same level (96). However, the difference in level in

379 the case of the sampled roads was always less than $1 \mathrm{~m}$ and in most cases was even

380 less than $0.5 \mathrm{~m}$. We think that these differences do not prevent hares from accessing

381 roads but can slow their ability to react if encountered by a vehicle, increasing the

382 likelihood of a collision. 
Coinciding with the findings of other authors, the majority of collision points

384 were near crossroads $(2 ; 3)$. The effect of crossroads differs between mammals and 385 may be related to the size of the animal involved. Ungulate collision points are far 386 from crossroads (95), which may suggest avoidance of these road sections or simply 387 that large ungulates are easier to see and avoid by vehicles in these open areas. Fence 388 gaps or ends at intersections may favour medium or large sized mammals' fatalities 389 near crossings (44). However, smaller size species are less visible and use road verges 390 to hide out (97) being more difficult to avoid the collision near these intersections.

391 Small mammals can also dig or pass easily under the fences, in case of roads fenced.

392 Finally, higher traffic volume is positively associated, as already known, to wildlife 393 fatalities (98). This is one the reasons why some roads are fenced: to make them safer 394 avoiding humans and wildlife access them.

\section{Possible mitigation strategies as conservation measures}

Possible mitigation measures for Iberian hare accidents ranges from improve

398 habitat connectivity on either side of the roads or to funnel animals to crossing

399 structures $(99 ; 100)$; to manage speed limits and traffic in the sections affected by

400 roadkills, fencing with adequate mesh sizes or removing vegetation in road verges and

401 bands of $50 \mathrm{~m}$ to $100 \mathrm{~m}$ free of vegetation at both sides of the road (100). However,

402 most of these measures are perceived as costly in already existing roads, appear to

403 have little influence on improving the situation $(102 ; 103)$, need appropriate and

404 constant maintenance (104) or may be contentious as, if inappropriately placed,

405 fences could exacerbate barrier effects and have even greater negative impacts for the 406 population than roadkills (105). Further, it should also consider individual variability 407 in behavioural response to roads (45) and be undertaken in the blackspots or carried 
408 out seasonally during the roadkill seasonal peaks (46). Focusing mitigation measures

409 on blackspots in new roads can be useful, but in older roads these sections may not be

410 the best option due to population depression (106).

411 Other optimal solutions must be sought $(62 ; 28)$. In diminished hare

412 populations, roads act as a clear threat and the creation of reserves without further

413 fragmentation have been recommended (8). The Andalusian network of protected

414 areas is already quite extensive but does not include plains and cultivated lands, where

415 the Iberian hare is mostly present. Hunting estates in the region may act as areas for

416 the protection of this species. Therefore, one possible mitigation measure arises from

417 a demographic point of view because hunting allows to regulate a species population

418 ecology when a sustainable harvesting is carried out. Given the economic and

419 viability obstacles that may arise in areas where most roads are old and go through

420 private farmlands or hunting estates, we propose to consider compensate the hunting

421 rates with the road accidents in the area as a first step in the mitigation strategy of

422 Iberian hare-vehicle accidents. This means that hare killed on roads should be taken

423 into account in hunting plans without forgetting other mitigation measures. Therefore,

424 we encourage careful consideration when assessing the local population status of

425 Iberian hares that include traffic and road mortality, before estimate hunting quotas. In

426 addition, given that hare hunting may accrue economic benefit for the local estates, a

427 proposed solution in an inter-disciplinary field like road ecology must consider also

428 whether reducing hunting quotas has any repercussions for estates' profit.

430 Conclusions

431 Finally, the results and discussion point to future directions for theoretical and 432 applied research in road ecology, which would include demographic compensation 
433 and roadkill or the assessment of specific mitigation measures to protect lagomorphs.

434 Due to the Iberian hare distribution as well as the common design of two-lane roads,

435 we consider also that our methods and results could help to the management of roads

436 and associated landscape throughout the national territory. In summary, this work

437 proposes a method that allows detecting favorable spatial configuration observing a

438 priori the spatial structure of a territory as preventive tools, and a propose a

439 modification in the management of hunting quotes only in territories with that

440 favorable spatial configuration by hare road kill blackspots. So, the implementation of

441 these measures could contribute to conserve an endemic Iberian lagomorph species

442 and indirectly also to maintaining Mediterranean landscape ecosystems.

444 References

445 1. Carvalho, F. \& Mira, A. Comparing annual vertebrate road kill over two time

446 periods, 9 years apart: a case study in Mediterranean farmland. Eur. J. Wildl. $447 \quad$ Res. 57, 157-174 (2011).

448 2. Freitas, S. R., Oliveira, N., Ciocheti, G., Vieira, M.V., Matos, D. M. \& Silva

449 Matos, D. M. How landscape features influence road-kill of three species of 450 mammals in the Brazilian savanna? Oecol. Aust. 18, 35-45 (2015).

451 3. Forman, R. T. \& Deblinger, R. D. The ecological road-effect zone of a 452 Massachusetts (USA) suburban highway. Conserv. Biol. 14, 36-46 (2000).

453 4. Coffin, A. W. From roadkill to road ecology: A review of the ecological effects of 454 roads. J. Transp. Geogr. 15, 396-406 (2007).

455 5. Goosem, M. Fragmentation impacts caused by roads through rainforests. Curr. Sci. $456 \quad 93,1587-1595$ (2007). 
457

458

459

460

461

462

463

464

465

466

467

468

469

470

471

472

473

474

475

476

477

478

479

6. Van der Ree, R., Smith, D. J. \& Grilo, C. In: Handbook of road ecology. (ed. John Wiley \& Sons) (2015).

7. Grilo, C., Reto, D., Filipe, J., Ascencão, F. \& Revilla, E. Understanding the mechanism behind road effects: linking occurrence with road mortality in owls. Anim. Conserv. 17, 555-564 (2014).

8. Roedenbeck, I. A. \& Voser, P. Effects of roads on spatial distribution, abundance and mortality of brown hare (Lepus europaeus) in Switzerland. Eur. J. Wildl. Res. 54, 425-437 (2008).

9. Putman, R. J. Deer and road traffic accidents: options for management. J. Environ. Manag. 51, 43-57 (1997).

10. Madsen, A. B., Strandgaard, H. \& Prang, A. Factors causing traffic killings of roe deer Capreolus capreolus in Denmark. Wildl. Biol. 8, 55-61 (2002).

11. Ng, J. W., Nielsen, C., Cassady, St. \& Clair, C. Landscape and traffic factors influencing deer-vehicle collisions in an urban environment. Human-Wildl. Conflic. 2, 34-47 (2008).

12. Philcox, C. K., Grogan, A. L. \& Macdonald, D. W. Patterns of otter Lutra lutra road mortality in Britain. J. App. Ecol. 36, 748-762 (1999).

13. Clevenger, A. P., Chruszcz, B. \& Gunson, K. E. Spatial patterns and factors influencing small vertebrate fauna roadkill aggregations. Biol. Conserv. 109, $15-26$ (2003).

14. Ascensão, F., Clevenger, A. P., Grilo, C., Filipe, J. \& Santos-Reis, M. Highway verges as habitat providers for small mammals in agrosilvopastoral environments. Biodiv. Conserv. 21, 3681-3697 (2012). 
480

481

482

483

484

15. Serronha, A., Mateus, A. R. A., Eaton, F., Santos-Reis, M. \& Grilo, C. Towards effective culvert design: monitoring seasonal use and behaviour by Meditteranean mesocarnivores. Environ. Monit. Assess 185, 6235-6246 (2013).

16. Heigl, F., Stretz, C. R., Steiner, W., Suppan, F., Bauer, T., Laaha, G. \& Zaller, J. G. Comparing road-kill datasets from hunters and citizen scientists in a landscape context. Remote Sens. 8, 832 (2016).

17. Seiler, A., Helldin, J. O. \& Seiler, C. Road mortality in Swedish mammals: results of drivers' questionnaire. Wildl. Biol. 10, 225-233 (2004).

18. Caro, T. M., Shargel, J. A. \& Stoner, C. J. Frequency of medium-sized mammal road kills in an agricultural landscape in California. Am. Midl. Nat. 144, 362-369 (2000).

19. Fudge, D., Freedman, B., Crowell, M., Nette, T. \& Power, V. Road-kill of mammals in Nova Scotia. Can. Field Nat. 121, 265-273 (2007).

20. Lee, G., Tak, J. H. \& Pak, S. I. Spatial and temporal patterns on wildlife road-kills on highway in Korea. J. Vet. Clin. 31, 282-287 (2014).

21. Palacios, F. On the taxonomic status of the genus Lepus in Spain. Acta Zool. Fenn. 174, 27-30 (1983).

22. Tapia, L., Domínguez, J. \& Rodríguez, J. Modelling habitat use by Iberian hare Lepus granatensis and European wild rabbit Oryctolagus cuniculus in a mountainous area in northwestern Spain. Acta Theriol. 55, 73-79 (2010).

23. Farfán, M. A., Duarte, J., Vargas, J. M. \& Fa, J. E. Effects of human induced landuse changes on the distribution of the Iberian hare. J. Zool. 286, 258-265 (2012).

24. Alzaga, V., Torres, J., Villanúa, D., Cormanzana, A., Lenaroz, I. \& MateoMoriones, A. Conocimientos científicos importantes para la conservación y 
gestión de las tres especies de liebre de la península Ibérica: deficiencias y retos para el futuro. Ecosistemas 22, 13-19 (2013).

25. Alves, P. C., Gonçalves, H., Santos, M. \& Rocha, A. Reproductive biology of the Iberian hare, Lepus granatensis, in Portugal. Mammalian Biology 67, 358-371 (2002).

26. Farfán, M. A., Vargas, J. M., Real, R., Palomo, L. J. \& Duarte, J. Population parameters and reproductive biology of the Iberian hare Lepus granatensis in southern Iberia. Acta Theriol. 49, 319-335 (2004a).

27. Fernández, A., Soriguer, R., Castién, E. \& Carro, F. Reproductive parameters of the Iberian hare Lepus granatensis at the edge of its range. Wildl. Biol. 14,

28. Martínez-Abraín, A., Jiménez, J. \& Oro, D. New policies for a new wildlife: A road map for the wildlife manager of the future. Biol. Conserv. 236, 484-488 (2019).

29. Carro, F., Beltrán, J. F., Márquez, F. J., Pérez, J. M. \& Soriguer, R.C. Supervivencia de la liebre ibérica en el parque nacional de Doñana durante una época de inundaciones. Galemys 14, 31-38 (2002).

30. Sánchez-García, C., Alonso, M. E., Bartolomé, D. J., Pérez, J. A., Larsen, R.T. \& Gaudioso, V. R. Survival, home range patterns, probable causes of mortality, and den-site selection of the Iberian hare (Lepus, Leporidae, mammalia) on arable farmland in north-west Spain. Italian J. Zool. 79, 590-597 (2012).

31. ESYRCE. Encuesta sobre Superficie y Rendimientos. Ministerio de Agricultura, Pesca y Alimentación. Subdirección General de Análisis, Coordinación y Estadística. Gobierno de España. Catálogo de Publicaciones de la 
Administración General del Estado: https://cpage.mpr.gob.es. N.I.P.O.: 003-19051-9 (2019).

531 32. Farfán, M. A. Evaluación de la gestión de la caza en Andalucía. Un ensayo de comarcalización cinegética. In: PhD thesis, Universidad de Málaga (2010).

33. Junta de Andalucía. In: Informe de Medio Ambiente en Andalucía 2018. (2018).

34. Péron, G. Compensation and additivity of anthropogenic mortality: life-history effects and review of methods. J. Anim. Ecol. 82, 408-417 (2012).

35. Capel-Molina, J. J. In: Los climas de España. Oikos-Tau Barcelona (1981).

36. Junta de Andalucía. In: Plan de aforos de la red principal de carreteras de Andalucía 2006. Mapa de Tráfico. Provincia de Málaga. Consejería de Obras

37. Nieto, J. M., Pérez, A. \& Cabezudo, B. Biogeografía y series de vegetación de la provincia de Málaga (España). Acta Bot. Malac. 16, 417-436 (1991).

38. García, A. \& Cano, E. In: Malas hierbas del olivar giennense. Diputación Provincial de Jaén, Jaén (1995).

39. Vargas, J. M., Farfán, M. A., Guerrero, J. C., Barbosa, A. M. \& Real, R. Geographical and environmental correlates of big and small game in Andalusia (southern Spain). Wildl. Res. 34, 498-506 (2007). Peninsula). Italian. J. Zool. 75, 161-172 (2008). 
41. Delibes-Mateos, M., Farfán, M. A., Olivero, J., Márquez, A. L. \& Vargas, J. M. Long-term changes in game species over a long period of transformation in the Iberian Mediterranean landscapes. Environ. Manage. 43, 1256-1268 (2009).

42. Delibes-Mateos, M., Farfán, M. A., Olivero, J., Vargas, J. M. Impact of land-uses changes on red-legged partridge conservation in the Iberian Peninsula. Environ. Conserv. 39, 337-346 (2012).

43. D’Amico, M., Périquet, S., Román, J., Revilla, E. Road avoidance responses determine the impact of heterogeneous road networks at a regional scale. $J$. Appl. Ecol. 53, 181-190 (2016).

44. Cserkesz, T., Ottleez, B., Cserkesz, A. \& Farkas, J. Interchange as the main factor determining wildlife-vehicle collision hotspots on the fenced highways: spatial analysis and applications. Eur. J. Wildl. Res. 59, 587-597 (2013).

45. Ascensão, F., Grilo, C., LaPoint, S., Tracey, J., Clevenger, A. P. \& Santos-Reis, M. Inter-individual variability of Stone Marten behavioral responses to a highway. Plos One 9, e103544 (2014).

46. D’Amico, M., Román, J., de los Reyes, L. \& Revilla, E. Vertebrate road-kill patterns in Mediterraean habitats: who, when and where. Biol. Conserv. 191, 234-242 (2015).

47. Santos, S. M., Lourenço, R., Mira, A. \& Beja, P. Relative effects of road risk, habitat suitability, and connectivity on wildlife roadkills: the case of the Tawny Owls (Strix aluco). Plos One 8, e79967 (2013).

48. Malo, J. E., Suárez, F. \& Díez, A. Can we mitigate animal-vehicle accidents using predictive models? J. App. Ecol. 41, 701-710 (2004).

49. Villalba, P., Reto, D., Santos-Reis, M., Revilla, E. \& Grilo, C. Do dry ledges reduce the barrier effect of roads? Ecological Engineering 57: 143-148 (2013). 
50. Duarte, J., Farfán, M. A., Fa, J. E. \& Vargas, J. M. Habitat-related effects on temporal variations in red-legged partridge Alectoris rufa abundance estimations in olive groves. Ardeola 61, 31-43 (2014a).

51. Magurran, A. E. In: Measuring biological diversity. (Blackwell, Malden, 2004).

52. Baxter, W. L. \& Wolfe, C. W. The interspersion index as a technique for evaluation a bobwhite quail habitat. In: National Quail Symposium Proceedings. $158-165$ (1972).

53. Litvaitis, J. A., Titus, K. \& Anderson, E. M. Measuring vertebrate use of terrestrial habitats and food. In: Bookhoud (ed. T.A., Research and management techniques for wildlife and habitats: The Wildlife Society Bethesda) 254-274 (1996).

54. Zar, J. H. In: Biostatistical analysis. 4th (ed. Prentice hall, Upper Saddle River, 1999).

55. Fowler, J. \& Cohen, L. In: Practical statistics for field biology. (Wiley, New York, 1992).

56. O’ Brien, R. M. A caution regarding rules of thumb for variance inflation factors. Qual. Quant. 41, 673-690 (2007).

57. Crawley, M. J. GLIM for ecologists. (Blackwell, London, 1993).

58. Akaike, H. Information theory and an extension of the maximum likelihood principle. In: Proceedings of the Second International Symposium on Information Theory. (eds. Petrov B. N., Csaki F.) 267-268 (Akade-miai Kiado Hungary, 1973).

59. Caletrio, J., Fernández, J.M., López, J. \& Roviralta, F. Spanish national inventory on road mortality of vertebrates. Global Biodiv. 5, 15-18 (1996). 
602

603

604

605

606

607

608

609

610

611

612

613

614

60. Pfeifer-Coelho, I., Coelho, A.V.P. \& Kindel, A. Roadkill of vertebrate species in two highways through the Atlantic forest biosphere reserve, southern Brazil. Eur. J. Wildl. Res. 54, 689-699 (2008).

61. Ruiz-Capillas, P., Mata, C. \& Malo, J. How many rodents die on the road? Biological and methodological implications from a small mammals' roadkill assessment on a Spanish motorway. Ecol. Res. 30, 417-427 (2015).

62. Polak, T., Rhodes, J. R., Jones, D. \& Possingham, H. P. Optimal planning for mitigating impacts of roads on wildlife. J. Appl. Ecol. 51, 726-734 (2014).

63. Canal, D., Camacho, C., Martín, B., de Lucas, M. \& Ferrer, M. Magnitude, composition and spatiotemporal patterns of vertebrate roadkill at regional scales: a study in southern Spain. Animal Biodivers. Conserv. 41, 281-300 (2018).

64. Moreira, J. M., Rodríguez, M., Zoido, F., Moniz, C., Venegas, C. \& Rodríguez, J. In: Atlas de Andalucía. Tomo II. (Consejerías de Medio Ambiente y Obras Públicas y Transportes de la Junta de Andalucía, Andalucía, España, 2005).

65. Ministerio de Agricultura, Pesca y Alimentación. In: Encuesta sobre superficies y Rendimientos (ESYRCE) de cultivos. Resultados nacionales y autonómicos. (Gobierno de España, España, 2019).

66. Santos, S. M., Carvalho, F. \& Mira, A. How long do the dead survive on the roads? Carcass persistence probability and implications for road-kill monitoring surveys. Plos One 6, e:25383 (2011).

67. Santos, S. M., Marques, J. T., Lourenço, A., Medinas, D., Barbosa, A. M., Beja, P. \& Mira, A. Sampling effects on the identification of roadkill hotspots: implications for survey design. J. Env. Manag. 162, 87-95 (2015). 
68. Driessen, M. M., Mallick, S. A. \& Hocking, G. J. Habitat of the eastern barred bandicoot, Perameles gunnii, in Tasmania: An analysis of road-kills. Wildl. Res. 23, 721-727 (1996).

69. Fahrig, L., Pedlar, J. H., Pope, S. E., Taylor, P. D. \& Wegner, J. F. Effect of Road Traffic on Amphibian Density. Biol. Conserv. 73, 177-182 (1995).

70. Bright, P. W., Balmforth, Z. \& MacPherson, J. L. The effect of changes in traffic flow on mammal road kill counts. App. Ecol. Env. Res. 1381, 171-179 (2015).

71. George, L. J., MacPherson, J. L., Balmforth, Z. \& Bright, P. W. Using the dead to monitor the living: can road kill counts detect trends in animal abundance? App. Ecol. Env. Res. 9, 27-41 (2011).

72. Farfán, M. A., Guerrero, J. C., Real, R., Barbosa, M. A. \& Vargas, J. M. Caracterización del aprovechamiento cinegético de los mamíferos en Andalucía. Galemys 16, 41-59 (2004b).

73. González-Gallina, A., Benítez-Badillo, G., Hidalgo-Mihart, M. G., Equihua, M. \& Rojas-Soto, O. R. Roadkill as a complementary information source for biological surveys using rodents as a model. J. Mammal. 97, 145-154 (2016).

74. Hobday, A. J. \& Minstrell, M. L. Distribution and abundance of roadkill on Tasmanian highways: human management options. Wildl. Res. 35, 712-726 (2008).

75. Bencin, H. L., Prange, S., Rose, C. \& Popscu, V. D. Roadkill and space use data predict vehicle-strike hotspots and mortality rates in a recovering bobcat (Lynx rufus) population. Sci. Rep. 9, 15391 (2019).

76. Romin, L. A. \& Bissonette, J. A. Deer-vehicle collisions: status of state monitoring activities and mitigation efforts. Wildl. Soc. Bull. 24, 276-283 (1996). 
77. Colino-Rabal, V. J., Bosch, J., Muñoz, M. J. \& Peris, S. J. Influence of new irrigated croplands on wild boar (Sus scrofa) road kills in NW Spain. Animal Biodivers. Conserv. 35, 247-252 (2012).

78. Keuling, O., Baubet, E., Duscher, A., Ebert, C., Fischer, C., Monaco, A., Podgórski, T., Prevot, C., Ronnenberg, K., Sodeikat, G., Stier, N. \& Thurfjell, H. Mortality rates of wild boar Sus scrofa L. in central Europe. European J. Wildl. Res. 59, 805-814 (2013).

79. Schwartz, A. L.W., Shilling, F. M. \& Perkins, S. E. The value of monitoring wildlife roadkill. Eur. J. Wildl. Res. 66, 18 (2020).

80. Schaub, M. \& Lebreton, J. D. Testing the additive versus the compensatory hypothesis of mortality from ring recovery data using a random effects model. Animal Biodivers. Conserv. 27, 73-85 (2004).

81. Nichols, J. D., Lancia, R. A. \& Lebreton, J. D. Hunting statistics: what data for what use? Game Wildl. Sci. 18, 185-205 (2001).

82. Bujoczek, M., Ciach, M. \& Yosef, R. Road-kills affect avian population quality. Biodivers. Conserv. 144, 1036-1039 (2011).

83. Loss, S. R., Will, T. \& Marra, P. P. Estimation of bird-vehicle collision mortality on U.S. roads. J. Wildl. Manag. 78, 763-771 (2014).

84. Grilo, C., Sousa, J., Ascensão, F., Matos, H., Leitão, I., Pinheiro, P., Costa, M., Bernardo, J., Reto, D., Lourenço, R., Santos-Reis, M. \& Revilla, E. Individual spatial responses towards roads: implications for mortality risk. Plos One 7, e43811 (2012)

85. Sandercock, B. K., Nilsen, E. B., Broseth, H. \& Pedersen, H. C. Is hunting mortality additive or compensatory to natural mortality? Effects of experimental 
harvest on the survival and cause-specific mortality of willow ptarmigan. $J$. Anim. Ecol. 80, 244-258 (2011).

86. Garrido, J. L., Gortázar, C. \& Ferreres, J. In: Las especies cinegéticas españolas en el siglo XXI. Garrido (ed., Independently Published), Spain.

$$
\text { http://hdl.handle.net/10261/217633 (2019). }
$$

87. Lopes, A. M., Marques, S., Silva, E., Magahaes, M. J., Pinheiro, A., Alves, P. C., Le Pendu, J., Esteves, P. J., Thompson, G. \& Abrantes, J. Detection of RHDV strains in the Iberian hare (Lepus granatensis): earliest evidence of rabbit lagovirus cross-species infection. Vet. Res. 45, 94 (2014).

88. Águeda-Pinto, A., Lemos de Matos, A., Abrantes, M., Kraberger, S., Risalde, M. A., Gortázar, C., McFaddem, G., Varsani, A. \& Esteves, P. J. Genetic characterization of a recombinant myxoma virus in the Iberian hare (Lepus granatensis). Virus 11, 530 (2019).

89. Nielsen, C. K., Anderson, R. G. \& Grund, M. D. Landscape influences on deervehicle accident areas in an urban environment. J. Wildl. Manag. 67, 46-51 (2003).

90. Finder, R. A., Roseberry, J. L. \& Woolf, A. Site and landscape conditions at white-tailed deer/vehicle collision locations in Illinois. Landsc. Urban Plan. 44, $77-85$ (1999).

91. Pauperio, J. \& Celio, P. Diet of the Iberian hare (Lepus granatensis) in a mountain ecosystem. Eur. J. Wildl. Res. 54, 571-579 (2008).

92. Garriga, N., Franch, M., Santos, X., Montori, A. \& Llorente, G. A. Seasonal variation in vertebrate traffic casualties and its implications for mitigation measures. Landsc. Urban Plan. 157, 36-44 (2017). 
93. Marboutin, E. \& Aebischer, N. J. Does harvesting arable crops influence the behaviour of the European hare (Lepus europaeus)? Wildl. Biol. 2, 83-91 (1996).

94. Duarte, J., Farfán, M. A., Fa, J. E. \& Vargas, J. M. Soil conservation techniques in vineyards increase passerine diversity and crops use by insectivorous birds. Bird Study 61, 193-203 (2014b).

95. Hubbard, M. W., Danielson, B. J. \& Schmitz, R. A. Factors influencing the location of deer-vehicle accidents in Iowa. J. Wildl. Manag. 64, 707-713 (2000).

96. Clevenger, A. P. \& Waltho, N. Factors influencing the effectiveness of wildlife underpasses in Banff National Park, Alberta, Canada. Conserv. Biol. 14, 47-56 (2000).

97. Rico-Guzmán, E., Cantó, J. L., Terrones, B. \& Bonet, A. Impacto del tráfico rodado en el PN del Carrascal de la Font Roja ¿Cómo influyen las características de la carretera en los atropellos de vertebrados? Galemys 23, 113-123 (2011).

98. Sadleir, R. M. F. S. \& Linklater, W. L. Annual and seasonal patterns in wildlife road-kill and their relationships with traffic density. New Zealand J. Zool. 43, 275-291 (2016)

99. Yanes, M., Velasco, J. M. \& Suárez, F. Permeability of roads and railways to vertebrates: The importance of culverts. Biol. Conserv. 71, 217-222 (1995).

100. Mata, C., Hervás, I., Herranz, J., Suárez, F. \& Malo, J. E. Complementary use by vertebrates of crossing structures along fenced Spanish motorways. Biol. Conserv. 124, 397-405 (2005). 
722 101. Rivera, D. Dejan de registrarse atropellos de fauna tras varias medidas en una 723 carretera extremeña. Quercus 407, 38-39 (2020).

724 102. Bissonette, J. A. \& Kassar, C. A. Locations of deer-vehicle collisions are unrelated to traffic volume or posted speed limit. Human Wildl. Conflict 2, 122-130 (2008).

103. Jancke, S. \& Giere, P. Pattern of otter Lutra lutra road mortality in a landscape abundant in lakes. Eur. J. Wildl. Res. 57, 373-381 (2011).

104. Farfán, M. A., Fa, J. E., Martín-Taboada, A., García-Carrasco, J. M. \& Duarte, J. Lack of maintenance of motorway fences works against their intended purpose with potential negative impacts on protected species. Sci. Rep. 10, 791 (2020).

105. Olsson, M. P. O. \& Widen, P. Effects of highway fencing and wildlife crossing on moose Alces alces movements and space use in southwestern Sweden. Wildl. Biol. 14, 111-117 (2008).

106. Zimmermann, F., Kindel, A., Hartz, S. M., Michell, S. \& Fahrig, L. When roadkill hotspots do not indicate the best sites for road-kill mitigation. J. App. Ecol. 54, 1544-1551 (2017).

\section{Acknowledgements}

We also thank S. Coxon for his help in the English revision of the manuscript.

\section{Declarations}

Declaration of competing interest. The authors declare that they have no known competing financial interests or personal relationships that could have appeared to influence the work reported in this paper. 
746 Conflicts of interest/Competing interests the authors declare that they have no

747 competing interests

748 Availability of data and material Not applicable

749 Code availability Not applicable

750 Ethics approval Not applicable.

751 Consent to participate All co-authors agree.

752 Consent for publication All co-authors agree.

753 


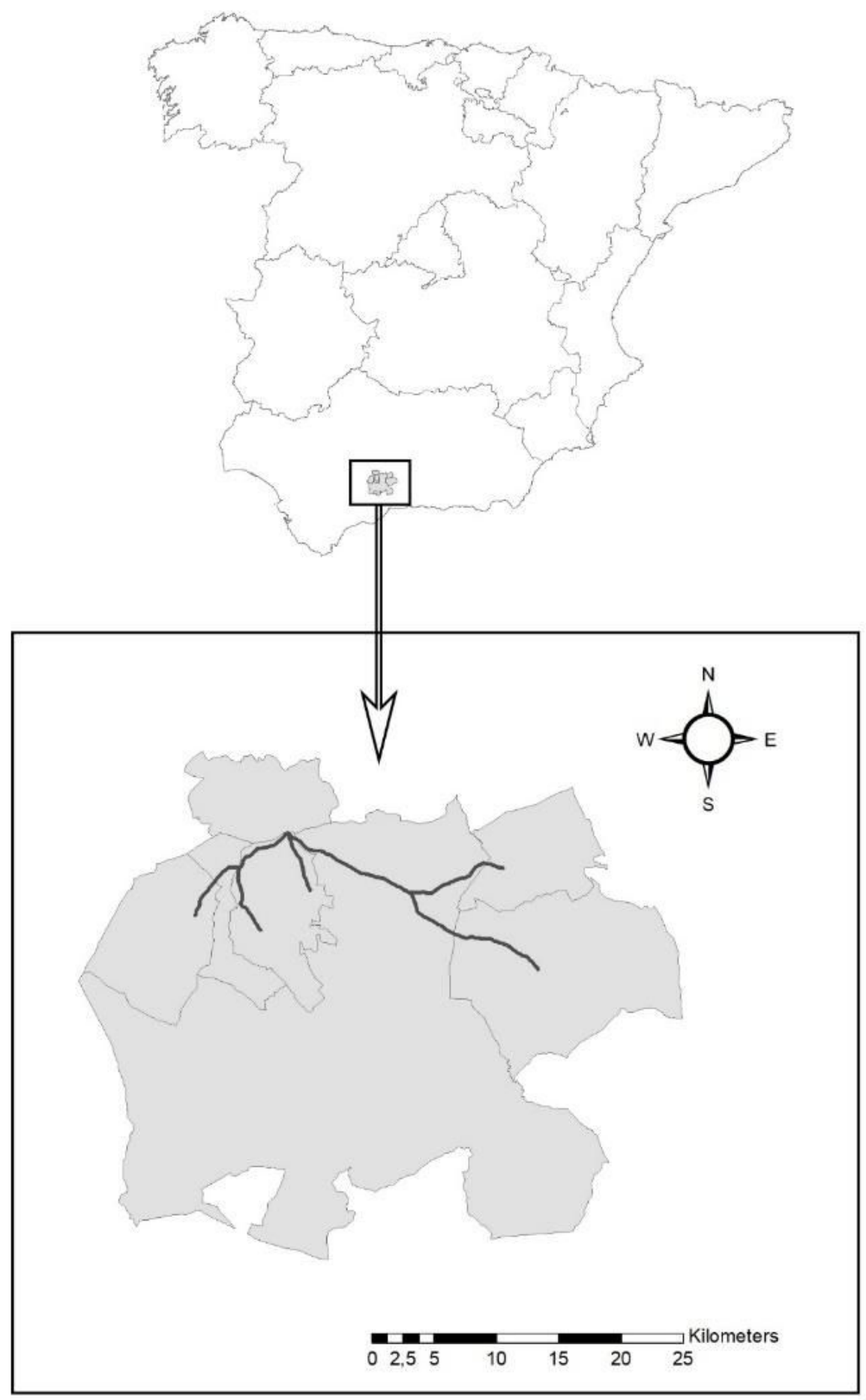

\section{Figure 1}

Location of the study area in the northeast of Malaga province to the southern of Spain. Stretches of highways analysis for hare roadkills $(55.7 \mathrm{~km})$. Note: The designations employed and the presentation of the material on this map do not imply the expression of any opinion whatsoever on the part of Research 
Square concerning the legal status of any country, territory, city or area or of its authorities, or concerning the delimitation of its frontiers or boundaries. This map has been provided by the authors.

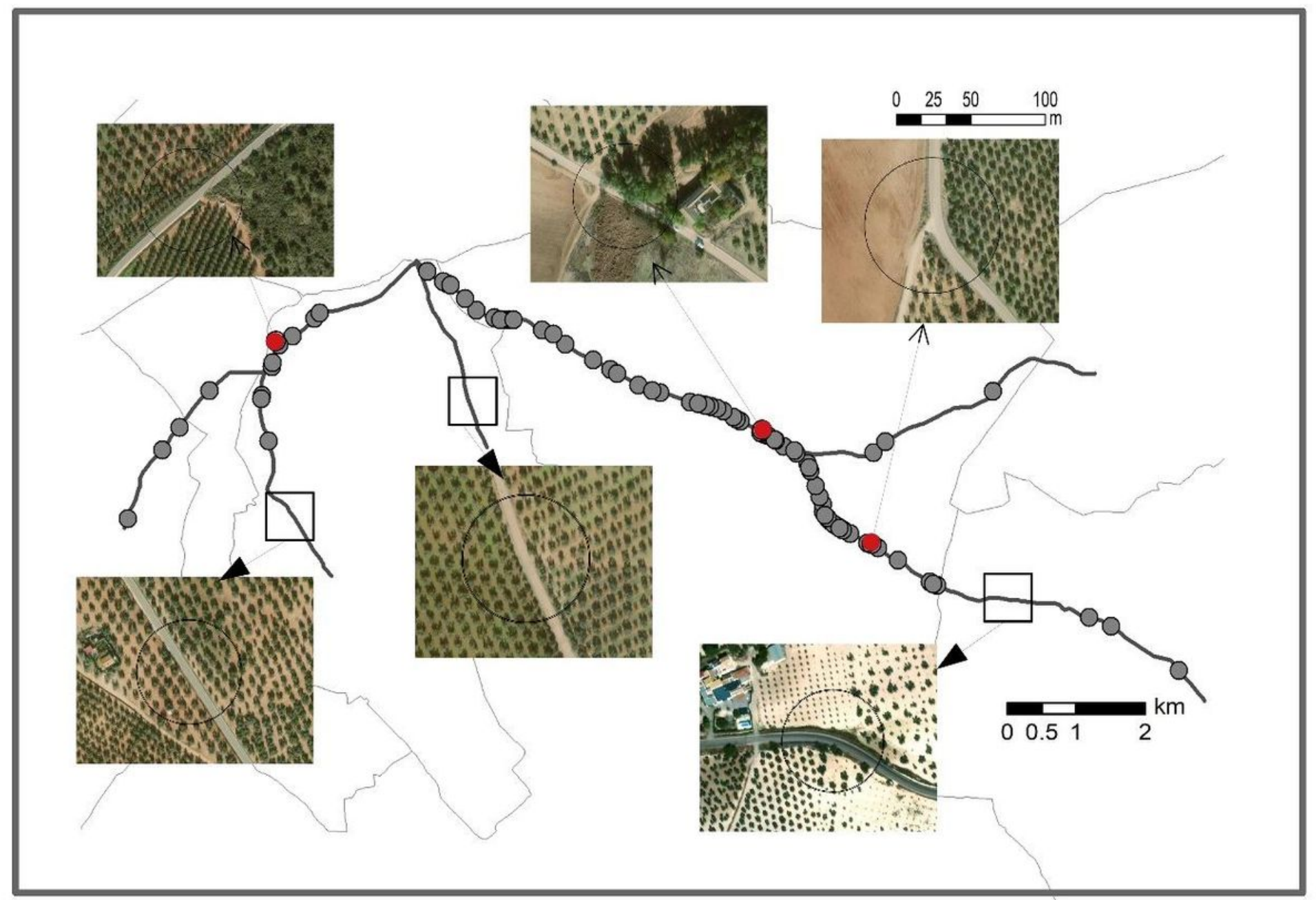

Figure 2

Spatial study context. Grey and red circles indicate the points with hare roadkill events; the red circles, those hare roadkill points that we have added a photograph with the around $100 \mathrm{~m}$ buffer habitat (showing heterogeneous habitats). Rectangles indicate some points without hare roadkill detected which we have added a photograph with the $100 \mathrm{~m}$ buffer habitat (showing homogeneous habitats). 